University of Nebraska - Lincoln

DigitalCommons@University of Nebraska - Lincoln

USDA Forest Service / UNL Faculty Publications U.S. Department of Agriculture: Forest Service -National Agroforestry Center

2013

Small Geographic Range but not Panmictic: How Forests

Structure the Endangered Point Arena Mountain Beaver

(Aplodontia rufa nigra)

\author{
William J. Zielinski \\ USDA Forest Service, bzielinski@fs.fed.us \\ Fredrick V. Schlexer \\ USDA Forest Service \\ Sean A. Parks \\ USDA Forest Service \\ Kristine L. Pilgrim \\ USDA Forest Service \\ Michael K. Schwartz \\ USDA Forest Service
}

Follow this and additional works at: https://digitalcommons.unl.edu/usdafsfacpub

Zielinski, William J.; Schlexer, Fredrick V.; Parks, Sean A.; Pilgrim, Kristine L.; and Schwartz, Michael K., "Small Geographic Range but not Panmictic: How Forests Structure the Endangered Point Arena Mountain Beaver (Aplodontia rufa nigra)" (2013). USDA Forest Service / UNL Faculty Publications. 260.

https://digitalcommons.unl.edu/usdafsfacpub/260

This Article is brought to you for free and open access by the U.S. Department of Agriculture: Forest Service -National Agroforestry Center at DigitalCommons@University of Nebraska - Lincoln. It has been accepted for inclusion in USDA Forest Service / UNL Faculty Publications by an authorized administrator of DigitalCommons@University of Nebraska - Lincoln. 


\title{
Small geographic range but not panmictic: how forests structure the endangered Point Arena mountain beaver (Aplodontia rufa nigra)
}

\author{
William J. Zielinski • Fredrick V. Schlexer • \\ Sean A. Parks • Kristine L. Pilgrim • \\ Michael K. Schwartz
}

Received: 21 December 2011/Accepted: 13 July 2012/Published online: 11 August 2012

(C) Springer Science+Business Media B.V. (outside the USA) 2012

\begin{abstract}
The landscape genetics framework is typically applied to broad regions that occupy only small portions of a species' range. Rarely is the entire range of a taxon the subject of study. We examined the landscape genetic structure of the endangered Point Arena mountain beaver (Aplodontia rufa nigra), whose isolated geographic range is found in a restricted $\left(85 \mathrm{~km}^{2}\right)$ but heterogenous region in California. Based on its diminutive range we may predict widespread gene flow and a relatively weak role for landscape variation in defining genetic structure. We used skin, bone, tissue and noninvasively collected hair samples to describe genetic substructure and model gene flow. We examined spatial partitioning of multilocus DNA genotypes and mitochondrial DNA haplotypes. We identified 3 groups from microsatellite data, all of which had low estimates of effective population size consistent with significant tests for historical bottlenecks. We used least-cost-path analysis with the microsatellites to examine how vegetation type affects gene flow in a landscape genetics framework. Gene flow was best predicted by a model with "Forest" as the most
\end{abstract}

Electronic supplementary material The online version of this article (doi:10.1007/s10592-012-0387-1) contains supplementary material, which is available to authorized users.

W. J. Zielinski $(\bowtie) \cdot$ F. V. Schlexer

USDA Forest Service, Pacific Southwest Research Station, Arcata, CA 95521, USA

e-mail: bzielinski@fs.fed.us

S. A. Parks

USDA Forest Service, Rocky Mountain Research Station,

Aldo Leopold Wilderness Research Institute, Missoula, MT 59801, USA

K. L. Pilgrim · M. K. Schwartz

USDA Forest Service, Rocky Mountain Research Station, Missoula, MT 59801, USA permeable, followed by "Riparian". Agricultural lands demonstrated the highest resistance. MtDNA data revealed only two haplotypes: one was represented in all 57 individuals that occurred north of the east-west flowing Garcia River. South of the river, however, both haplotypes occurred, often at the same site suggesting that the river may have affected historical patterns of genetic divergence.

Keywords Landscape genetics - Genetic substructure Mountain beaver - Aplodontia rufa . California

\section{Introduction}

The discipline of landscape genetics provides an approach to evaluate animal movement and gene flow in complex landscapes (Manel et al. 2003). Most current landscape genetic efforts, however, evaluate landscape impacts on gene flow across broad spatial extents but only include a small portion of a species range (e.g., Broquet et al. 2006; Coulon et al. 2004; Epps et al. 2007; Wang et al. 2009). It is uncommon to evaluate the entire range of a taxon, particularly when it is small. Under these circumstances it is often assumed that moderate movement will lead to relatively good mixing of genes. In this study we examine the landscape genetic structure of the Point Arena mountain beaver (Aplodontia rufa nigra) whose entire range is small but the landscape itself is very heterogeneous, potentially highlighting the importance of landscape vegetation structure across small scales.

The mountain beaver is the only extant member of the monotypic genus Aplodontia, first described by Rafinesque in 1817 (Taylor 1918). The Point Arena mountain beaver (A. rufa nigra) is one of 7 recognized subspecies (Hall 1981) and occurs in coastal California (Mendocino County; 
Fig. 1). It occupies a small, $85 \mathrm{~km}^{2}$, geographic range and is disjunct from the 3 other subspecies in California (Camp 1918; Steele and Litman 1998; USFWS 1998; USFWS 2009). Aplodontia rufa nigra was listed as "Endangered" by the U.S. Fish and Wildlife Service in 1991 under the Endangered Species Act due to threats posed by land conversion for agriculture, urban development, construction of transportation and utility corridors, livestock grazing, human disturbance, and other factors, combined with its highly restricted distribution (USFWS 1991). The taxon may have been more widely distributed prior to the development of livestock grazing in the region, which is presumed to have reduced the extent of historical coastal scrub habitat and contributed to the limited distribution of relatively few populations with few individuals (USFWS 1998). Several conservation documents have called for the evaluation of substructure within the Point Arena mountain beaver (USFWS 1998; USFWS 2009).

Although the geographic range of the subspecies is small, the Point Arena (PA) mountain beaver occupies varied habitats within its range. Near the coast it occurs in shrub and grasslands (Zielinski et al. in review) and inland it occurs in forest openings and near streams (Billig and Douglas 2007). These two habitats are often separated by intervening agricultural and range lands that are typically unsuitable. Given these circumstances, we hypothesize that if there was significant genetic substructure within the subspecies it might be revealed by examining the partitioning of genetic variance between western (coastal) and eastern (forest) populations that included a north-south sampling gradient. We also posit that if the subspecies is limited by the availability of water, as suggested by some previous research (Feldhamer et al. 2003; Gyug 2000; Nungesser and Pfeiffer 1965), and occurs primarily along streams (regardless of vegetation type), that gene flow would be influenced by the streamcourse or watershed where samples were collected. We test alternative models where gene flow is affected by landscape features such as vegetation type, anthropogenic disturbance, and streamcourse. We then model the path of least resistance (the least cost path; Walker and Craighead 1997) for each of several landscape resistance hypotheses. This will help address one of the key PA mountain beaver recovery criteria: the determination of "population interconnectivity, travel, and dispersal habitat" (USFWS 1998) and the protection of those lands identified as critical for connectivity.

\section{Methods}

Field methods

We consulted maps of the known distribution of PA mountain beaver, developed by the US Fish and Wildlife
Service from a variety of non-systematic sources (J. Hunter, pers. comm.), to determine potential sampling sites from across the PA mountain beaver's geographic range. Many locations are on private lands, so we could only access a subset of them. We attempted to sample from the eastern, western, northern and southern portions of the range as well as to include coastal and the inland regions of all the major east-west oriented stream systems within the subspecies' range: Mallo Pass Creek, Alder/Owl Creek, Garcia River/Hathaway Creek, Point Arena Creek and Moat Creek (Fig. 1). These samples were combined with more abundant samples from our primary ecological study areas in Manchester State Park (MSP): Kinney Beach and Alder Creek (Zielinski et al. in review), and from other locations in MSP, to create the range-wide survey database (Table 1).

Two methods were used to collect DNA samples: hair snaring and direct capture. Hair snare sample collection was developed during the course of estimating PA mountain beaver population sizes during the fall at 2 sites within Manchester State Park (Zielinski et al. in review). A snare was a gun-cleaning brush wired to a small landscape stake and inserted into the lateral wall of a burrow; 2 snares were placed in each burrow, on opposing sides. We placed a piece of apple on the burrow floor, between the snares, to increase the efficiency of snaring hairs (Zielinski et al. in review). Hair snaring outside of the park populations was conducted in a similar manner, except that snaring occurred at all times of year and the frequency at which snares were checked was less regulated. Samples collected from both snares in a single burrow were pooled. All samples were labeled in the field and placed in a silica gel indicator desiccant (Sorbead Orange or Blue to Pink, eCompressedair, Tulsa, Oklahoma, USA) within $24 \mathrm{~h}$ of collection.

We also collected hair and ear tissue punches directly from animals captured in live traps. Samples came from this source during our original field research, in 2004 and 2005, which involved live capture of all study animals, and again during the spring of 2009. The latter effort was an attempt to determine whether it was more efficient to collect hair or tissue directly from animals in hand, than to sample DNA from snared hair samples. Bone samples were collected when skeletal remains were discovered in the field.

The locations where animal samples were collected were assigned a geographic location based on the degree of accuracy obtained during field work. Universal Transverse Mercator (UTM) locations for individuals at our population study sites in Manchester State Park were obtained using a Trimble GeoExplorer II GPS device with accuracy $\pm 2 \mathrm{~m}$. All other locations were determined using a Garmin GPS device with accuracy $\pm 10 \mathrm{~m}$. For some analyses, when locations of individual samples occurred within a 1-2 ha 
Fig. 1 Locations for each of the 17 PA mountain beaver sites where samples from one or more individuals were collected, identified by their abbreviated names (full names provided in text)

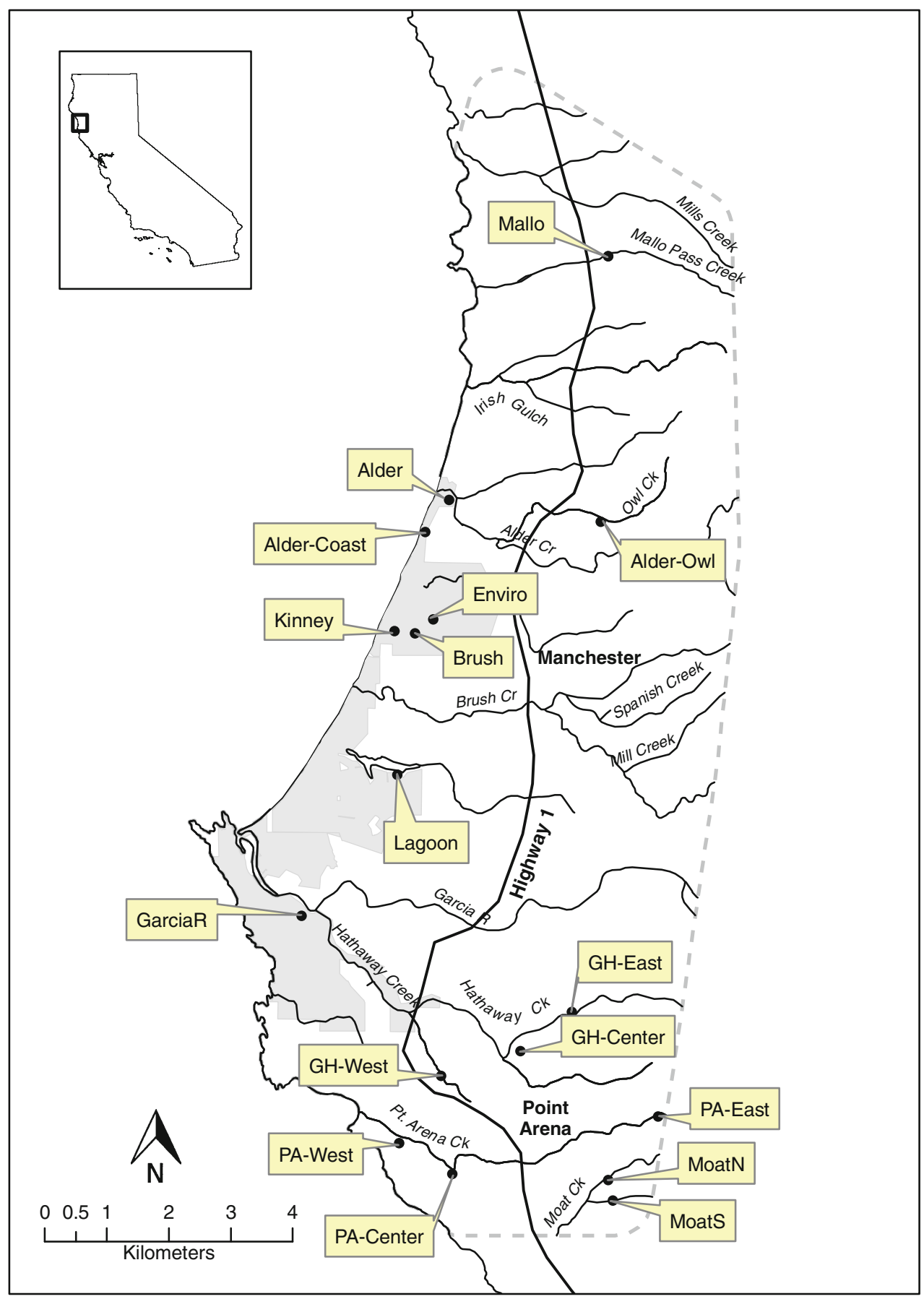

area they were combined and referred to as originating from one of 17 locations that we refer to as PA mountain beaver "sites" (Fig. 1).

\section{Laboratory methods}

We extracted DNA from tissue and hair samples using the QIAGEN DNEASY tissue kit (QIAGEN Inc., Germany) and manufacturer protocols. A hair sample comprised hairs pooled from both snares at a single burrow. The number of hairs ranged from one to hundreds, but were typically $>10$. When a hair sample included greater than 10 hairs, we selected 10 hairs with intact follicles; when there were $<10$ hairs we extracted the entire sample assuming that the hairs from each pair of snares were deposited by a single individual (Zielinski et al. in review). There were no instances of 3 alleles at a locus, which would have been indicative of multiple individuals. Samples that successfully amplified used an average of $6.6(\mathrm{SD}=3.2)$ hairs per extraction, while those that failed used $5.0(\mathrm{SD}=3.5)$ hairs (Zielinski 
Table 1 Distribution of 141 individual Point Arena mountain beavers in the: (A) 5 stream systems and 2 general locations (Kinney Beach and Camp/Dunes/EnvironmentalTrail/Stoneboro) with their corresponding coastal and inland regions, and (B) 17 PA mountain beaver sites, their short names, the total number of samples from each, and the years samples were collected

\begin{tabular}{|c|c|c|c|c|}
\hline \multirow{2}{*}{$\begin{array}{l}\text { A } \\
\text { Stream system or location (from north to south) }\end{array}$} & \multicolumn{2}{|c|}{ Coastal } & \multicolumn{2}{|c|}{ Inland } \\
\hline & $n$ & Sex ratio ${ }^{a}$ & $n$ & Sex ratio \\
\hline Mallo Pass Creek/Irish Gulch & 0 & & 3 & $1: 1: 1$ \\
\hline Alder Creek/Owl Creek & 28 & $13: 11: 4$ & 9 & $4: 2: 3$ \\
\hline Kinney Beach & 51 & $22: 23: 6$ & 0 & \\
\hline Camp/Dunes/Environmental Trail/Stoneboro & 8 & $4: 4: 0$ & 0 & \\
\hline Garcia River/Hathaway Creek & 10 & $5: 5: 0$ & 16 & 10:6:0 \\
\hline Point Arena Creek & 5 & $3: 1: 1$ & 1 & 1:0:0 \\
\hline Moat Creek & 0 & & 10 & $5: 5: 0$ \\
\hline Total & 102 & & 39 & \\
\hline
\end{tabular}

\begin{tabular}{|c|c|c|c|}
\hline $\begin{array}{l}B \\
\text { Point Arena mountain beaver site }\end{array}$ & Short name & Number of individuals & Year(s) collected \\
\hline Mallo Pass Creek & Mallo & 3 & 2006 \\
\hline Alder Creek/Owl Creek & Alder-Owl & 10 & $2007-2008$ \\
\hline Alder Creek & Alder & 27 & 2004-2008 \\
\hline Alder Coast & Alder Coast & 1 & 2004 \\
\hline Environmental Trail & Enviro & 5 & 2004 \\
\hline Brush Creek & Brush & 1 & 2004 \\
\hline Kinney Beach & Kinney & 51 & 2004-2008 \\
\hline Lagoon & Lagoon & 1 & 2005 \\
\hline Garcia River & GarciaR & 10 & 2007-2009 \\
\hline Garcia River-Hathaway Creek West & GH-West & 2 & 2006 \\
\hline Garcia River-Hathaway Creek East & GH-East & 1 & 2006 \\
\hline Garcia River-Hathaway Creek Center & GH-Center & 13 & 2009 \\
\hline Point Arena Creek East & PA-East & 1 & 2008 \\
\hline Point Arena Creek West & PA-West & 4 & 2006, 2008-2009 \\
\hline Point Arena Creek Center & PA-Center & 1 & 2006 \\
\hline Moat Creek North & MoatN & 9 & 2006,2008 \\
\hline Moat Creek South & MoatS & 1 & 2008 \\
\hline
\end{tabular}

${ }^{a}$ Males:Females:Unknown

et al. in review). Bone samples were extracted in a separate facility following recommended protocols.

For a pilot set of samples $(n=20)$, we sequenced the cytochrome $b$ region of mitochondrial DNA using primers CanidLl and H15149 (Kocher et al. 1989; Paxinos et al. $1997)$ to test species identification. The reaction volume $(50 \mu \mathrm{l})$ contained $50-100 \mathrm{ng}$ DNA, $1 \times$ reaction buffer (Perkin-Elmer, Waltham, Massachusetts, USA), $2.5 \mathrm{mM}$ $\mathrm{MgCl}_{2}, 200 \mu \mathrm{M}$ each dNTP, $1 \mu \mathrm{M}$ each primer, and $1 \mathrm{U}$ Taq polymerase (Perkin-Elmer). The PCR program was $94{ }^{\circ} \mathrm{C} / 5 \mathrm{~min}, \quad\left[94^{\circ} \mathrm{C} / 1 \mathrm{~min}, \quad 50{ }^{\circ} \mathrm{C} / 1 \mathrm{~min}, \quad 72^{\circ} \mathrm{C} / 1 \mathrm{~min}\right.$ $30 \mathrm{~s}] \times 34$ cycles, $72^{\circ} \mathrm{C} / 5 \mathrm{~min}$. Subsequently, we separated mountain beavers from other species that use their burrows by screening with 3 polymorphic microsatellite loci developed specifically for mountain beavers (Pilgrim et al. 2006). This approach saved resources by avoiding an initial species identification test since DNA of species other than mountain beaver fails to amplify with these primers. Samples that amplified successfully were then genotyped at 6 additional loci (Pilgrim et al. 2006). DNA was amplified with polymerase chain reaction (PCR) using a reaction volume of $10 \mu \mathrm{l}$ containing $2.0 \mu \mathrm{L}$ DNA, $1 \times$ reaction buffer (Perkin-Elmer), $2.5 \mathrm{mM} \mathrm{MgCl}_{2}, 200 \mu \mathrm{M}$ of each dNTP, $1 \mu \mathrm{M}$ reverse primer, $1 \mu \mathrm{M}$ dye-labeled forward primer, $1.5 \mathrm{mg} / \mathrm{ml}$ BSA, and 1U AmpliTaq Gold polymerase (Applied Biosystems, Carlsbad, California, USA). The PCR profile was $94{ }^{\circ} \mathrm{C} / 5 \mathrm{~min},\left[94{ }^{\circ} \mathrm{C} / 1 \mathrm{~min}, \mathrm{X}{ }^{\circ} \mathrm{C} /\right.$ $1 \mathrm{~min}, 72{ }^{\circ} \mathrm{C} / 30 \mathrm{~s}$ ] for 45 cycles, where $\mathrm{X}$ is a primer- 
specific temperature detailed in Pilgrim et al. (2006). PCR products were run in a $6.5 \%$ acrylamide gel for $2 \mathrm{~h}$ on a LI-COR DNA analyzer (LI-CORBiosciences, Inc., Lincoln, Nebraska, USA). Sex determination was performed using the zinc-finger region of the $\mathrm{X}$ and $\mathrm{Y}$-chromosomes amplifying with general mammalian primers (García-Muro et al. 1997) and a sex-specific test developed for mountain beavers (Pilgrim et al. 2012). After the amplification of the 9 loci, we assessed which hairs represented unique individuals, using the recapture function in the program Dropout (McKelvey and Schwartz 2005; Schwartz et al. 2006). We amplified only the unique individuals with an additional 3 loci $(A r E 04 F$, ArA08F, and $A r G 05 F)$ using the protocols described in Piaggio et al. (2009).

\section{Microsatellite data}

We tested microsatellite genotypes for departures from Hardy-Weinberg (HW) equilibrium at each locus using Fisher's exact test in GENEPOP 4.0 (Raymond and Rousset 1995; Rousset 2008). We used GENEPOP to calculate observed and expected heterozygosity and $\mathrm{F}_{\mathrm{IS}}$ and FSTAT (Goudet 2001) to estimate genetic differentiation among groups. $\mathrm{F}_{\mathrm{ST}}$ was calculated according to the method of Weir and Cockerham (1984), a method that is unbiased by sample size effects.

We used two different clustering methods to group samples according to their genetic similarity. First, as an exploratory analysis, we counted the number of alleles that were different between all pairs of individuals. We used this measure of genetic difference in a principal coordinates analysis (PCA) conducted in GENALEX (Peakall and Smouse 2006) and examined the graphical output for obvious cluster patterns. Secondly, we used program STRUCTURE (v2.3.3; Falush et al. 2007) to estimate the number of multilocus genetic groups $(k)$ in our sample and to assign individuals to these groups. STRUCTURE assigns individual multi-locus genotypes to population groups, minimizing Hardy-Weinberg deviations and linkage disequilibrium. We used an admixture model in STRUCTURE with correlated allele frequencies to test for the number of genetic groups (between 1 and 10). We used a "burn in" of 100,000 Markov Chain Monte Carlo repetitions to ensure that the log likelihood values became stable and the results were consistent among duplicate efforts (Pritchard et al. 2000). We then evaluated the fraction of each individual genome $(Q)$ and its relationship to each of $k$ groups, assigning individuals to a group if their individual $Q$ exceeded a natural break in the distribution of these values (e.g., McDevitt et al. 2009). Once we identified the number of groups, and their members, we estimated pairwise $F_{S T}$ values among the groups to evaluate the levels of intergroup similarity. Finally, we visualized the population structure results using program DISTRUCT (Rosenberg 2004).

We also explored genetic variation using a priori classification of individuals to one of the 17 different geographically separate entities, referred to as "sites" (Table 1; Fig. 1). Because mountain beavers tend to occur in spatially distinct groups across a landscape or region (Arjo et al. 2007; Beier 1989) we expected individuals from these distinct locations to be more genetically similar to one another. Thus, we expected to more effectively evaluate genetic substructure across the geographic range using this level (i.e., the site) of clustering. Sites averaged 8.29 individuals (range 1-51 [Kinney population]; Table 1). We used principal components analysis to explore genetic grouping (as implemented in program PCAGEN; Goudet 1999) among the sites.

\section{Mitochondrial data}

We used universal mammalian primers L15926 and H16498 (Kocher et al. 1989; Shields and Kocher 1991) to amplify approximately $800 \mathrm{bp}$ of the left hypervariable domain of the control region from six tissue samples. Internal primers were designed specifically to Aplodontia sequences to amplify a 444 bp fragment; $P A M B-L 2\left(5^{\prime}-\right.$ AGGTCAAGAAGAGGGACACG-3') and PAMB-R4 (5'CCCAAAGCTGACATTCTATTT- $3^{\prime}$ ). The amplification reactions were carried out using the same volumes and cycling profile as described above for species identification. The quality and quantity of template DNA were determined by $1.6 \%$ agarose gel electrophoresis. PCR products were purified using ExoSap-IT (Affymetrix-USB Corporation, OH, USA) according to manufacturer's instructions.

DNA sequence data was obtained using the Big Dye kit and the 3700 DNA Analyzer (ABI; High Throughput Genomics Unit, Seattle, WA, USA). Primers used for amplification were also used for single-stranded cycle sequencing reactions. Sequences were viewed and aligned with Sequencher (Gene Codes Corp. MI, USA).

\section{Geographic Information System (GIS) analysis}

We plotted the locations associated with each of the $k$ multilocus genetic groups in ArcMap (ESRI, Redlands, California, USA) and visually assessed whether these groupings corresponded to watersheds or vegetation cover types. Eight watersheds were identified by assigning each of the streams where we collected samples into one of the Calwater watersheds (California Interagency Watershed Mapping Committee, Davis, California, USA). Thus, all watersheds had at least one sample location. Streams were assigned to a watershed via visual inspection of digital orthophoto quads 


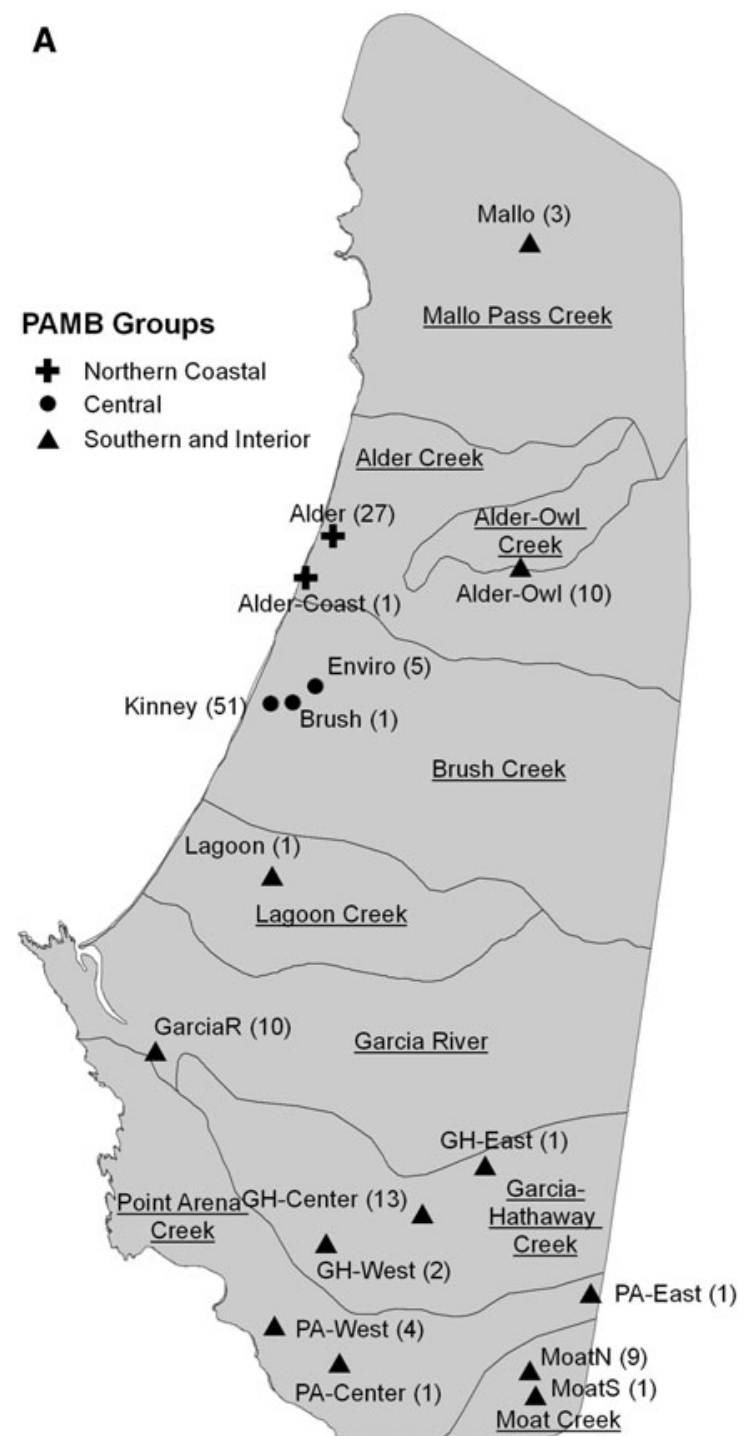

Fig. 2 a Watersheds within the range of the Point Arena mountain beaver (names underlined), with the locations of the 17 PA mountain beaver sites noted as symbols and identified by their abbreviations. Different symbols (cross, circle or diamond) represent membership in one of the 3 groups identified by program STRUCTURE. Numbers in parentheses indicate the number of individuals sampled at each site.

and were identified using CalWater Version 2.2.1 (1999; http://cain.ice.ucdavis.edu/calwater/) (Fig. 2a).

A vegetation GIS layer was used to relate gene flow to landscape vegetation features. The source vegetation GIS layers (fveg02_2, cveg98_2_23; Land Cover Mapping and Monitoring Program, California Department of Forestry and Fire Protection, Sacramento, California, USA) included 17 vegetation types identified using the CWHR (California Wildlife Habitat Relationships) system. The vegetation data were based on imagery from either 1998 or 2002 and used a1ha minimum mapping unit (for details: http://frag.cdf.ca. gov/projects/land_cover/index.html). Each of the 17 CWHR types was reclassified as belonging to one of four vegetation
B

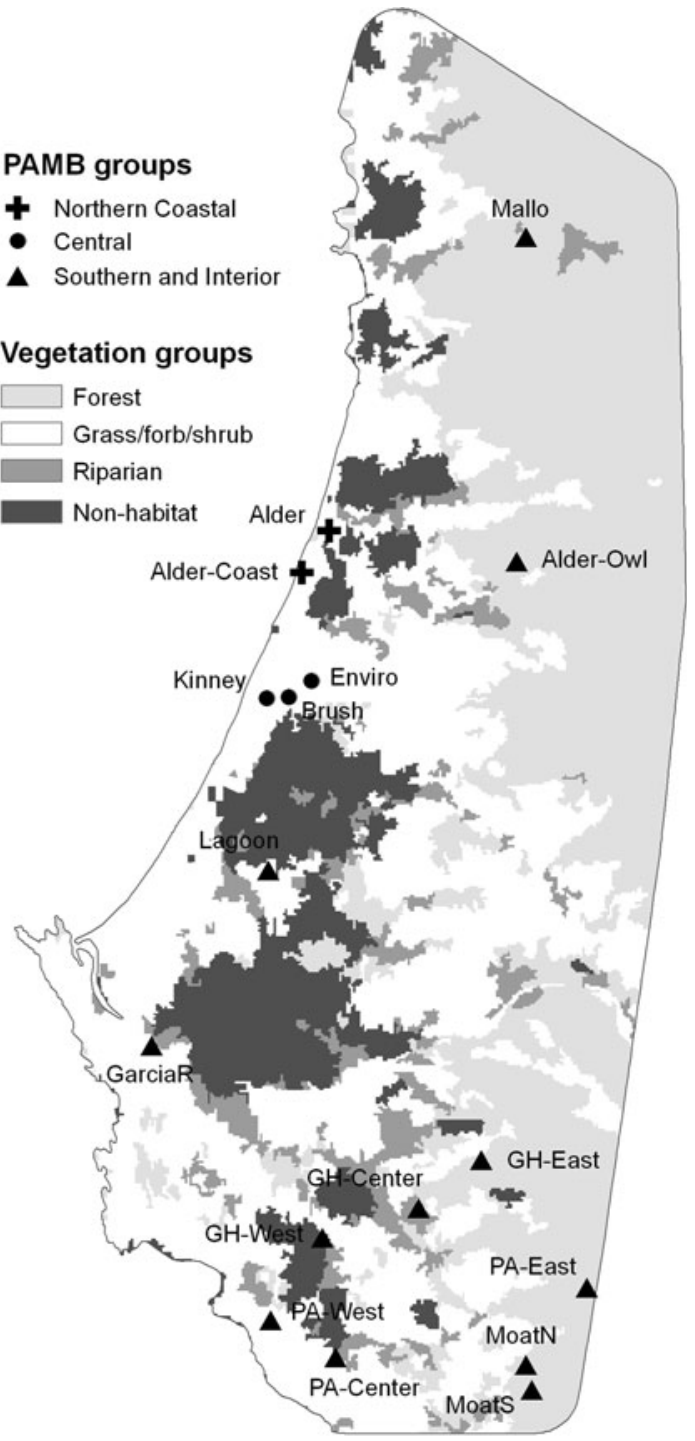

b Vegetation types within the range of the Point Arena mountain beaver with the locations of the 17 PA mountain beaver sites noted as symbols and identified using their abbreviations. Different symbols (cross, circle or diamond) represent membership in one of the 3 groups identified by program STRUCTURE. Numbers in parentheses indicate the number of individuals sampled at each site

types (Riparian, Forest, Grass/Shrub/Forbs and Non-Habitat; Table 2; Fig. 2b). These aggregate categories were created to simplify the analysis by maximizing among-type differences in habitat structure. For example, CPC [Closed Cone Pine-Cypress] was assigned to Forest and CRP [Crops/ Agriculture] was assigned to Non-Habitat. The Riparian type included two dominant streamside vegetation types, Montane Riparian and Valley Foothill Riparian, but in some of our model runs we also included as Riparian the 30-m pixels where streams occurred, based on a statewide hydrology GIS layer (Teale Data Center and California Fish and Game 1998), regardless of vegetation type. We plotted the locations of each of the individuals for which a haplotype was 
Table 2 California Wildlife Habitat Relationships (CWHR) habitat types found within the range of the Point Arena mountain beaver, aggregated into four vegetation types

\begin{tabular}{lll}
\hline Vegetation type & CWHR code & Habitat type \\
\hline Forest & CPC & Closed cone pine-cypress \\
& DFR & Douglas-fir \\
& MHC & Montane hardwoods conifer \\
& MHW & Montane hardwood \\
& RDW & Redwood \\
& ROG & Redwood, old growth \\
& RYG & Redwood, second growth \\
Grass/Shrub/Forbs & AGS & Annual grass \\
& BAR & Barren \\
& CSC & Coastal scrub \\
Riparian & MRI & Montane riparian \\
& VRI & Valley foothill riparian \\
Non-Habitat & CRP & Crops/Agriculture \\
& DRY & Dry lake bed \\
& EST & Estuarine \\
& LAC & Lacustrine \\
& URB & Urban \\
\hline
\end{tabular}

identified on the background of the major stream systems in the study area, assuming that topographic variation would most likely affect the historical gene flow.

\section{Bottlenecks and effective population size $\left(\mathrm{N}_{\mathrm{e}}\right)$}

We applied two tests to identify bottlenecks (as implemented in program BOTTLENECK; Piry et al. 1999) on two groups from the multilocus genetic data: (1) the groups identified as distinct by program STRUCTURE and (2) the sites with $\geq 9$ individuals sampled $(n=6)$. The first test examined the shape of the distribution of allele frequencies; populations that have undergone a bottleneck will lose rare alleles and demonstrate an increase in frequency of common alleles (Cornuet and Luikart 1996). The second test identified heterozygosity excess at mutation-drift equilibrium, a key genetic characteristic of demographically bottlenecked populations (Luikart et al. 1999). The average expected heterozygosity at mutation-drift equilibrium was calculated using 1,000 replications assuming a two-phase mutational model (Luikart et al. 1999). We ran simulations with $30 \%$ multistep mutations in the two-phase model with a variance of 12 . The observed heterozygosity was compared to the heterozygosity expected at equilibrium using a Wilcoxon signed-rank test (Luikart et al. 1999).

We estimated $\mathrm{N}_{\mathrm{e}}$ for each of the PAMB sites with sample sizes $\geq 9$, using a linkage disequilibrium based effective population size estimator (LDNE, Waples and Do 2008, 2010). We also estimated $\mathrm{N}_{\mathrm{e}}$ for each of the $k$ groups identified in our substructure analysis, excluding individuals that were not strongly assigned to a STRUCTURE group. We recognize that this approach may miss rare alleles and individuals that recently immigrated to a group, thus we also estimated $\mathrm{N}_{\mathrm{e}}$ using the geographic breaks identified with STRUCTURE (but including all individuals) recognizing that this may increase linkage disequilibrium due to population substructure and thus reduce $\mathrm{N}_{\mathrm{e}}$. However, we felt that comparing estimates from a priori groups with the larger geographic regions identified by STRUCTURE may also inform our view of the estimates of $\mathrm{N}_{\mathrm{e}}$. The larger geographic regions, wherein all individuals were included, were referred to as: "north of Alder Creek", "between Alder Creek and the Garcia River", and "south of the Garcia River", and roughly correspond to the regions specified by the results from STRUCTURE. We used LDNE under both the random mating and monogamy models only for alleles with frequencies $\geq 0.05$ to avoid bias associated with extremely rare alleles. The $95 \%$ confidence intervals were estimated assuming a parametric distribution, although estimates using a jack-knife approach were very similar (data not reported). $\mathrm{N}_{\mathrm{e}}$ estimates often can vary positively with sample size (Palstra and Ruzzante 2008), but the LDNE method accounts for this effect.

\section{Modeling gene flow}

We used least-cost path modeling (Walker and Craighead 1997) to evaluate the effect of landscape vegetation features on genetic structure. First, we calculated Euclidean (straight line) distances among the sites. We then evaluated a limited number of ecological hypotheses about the relative ease with which mountain beavers move through different vegetation types. We restricted the number of models we evaluated due to concerns that too many models can lead to spurious inference and limited our a priori hypotheses to prevailing theories about the movements of mountain beavers. We tested these with models and used the initial results to hierarchically test a second set of models to refine parameters. Each of these models resulted in an "ecological distance" among the sites. Ecological distance specifies the least-cost path given alternative models for movement among vegetation types. We used matrix regression (the "ecodist" package in $\mathrm{R}$ ) to examine the relationship of Euclidean distance, genetic distance, and ecological distance (as specified by the alternative ecological hypotheses) when applied to pairs of sites. This allowed us to determine whether ecological or Euclidean distance had a stronger relationship to genetic distance.

Alternative models for ecological distances were generated from a set of 16 different resistance scenarios by varying the relative resistance values for the vegetation types in a hierarchical manner (e.g., Table 3). We initially ran models 1-4 (Table 3) and, based on these results, 
Table 3 Resistance values (costs) for each land cover type for each landscape scenario for the Point Arena mountain beaver

\begin{tabular}{lllll}
\hline Model number & \multicolumn{4}{l}{ Habitat type } \\
\cline { 2 - 5 } & Riparian & Forest & Grass/shrub/forbs & Non-habitat \\
\hline Cost 1 & 1 & 3 & 5 & 25 \\
Cost 2 & 1 & 5 & 3 & 25 \\
Cost 3 & $1^{\mathrm{a}}$ & 3 & 5 & 25 \\
Cost 4 & $1^{\mathrm{a}}$ & 5 & 3 & 25 \\
Cost 5 & 1 & 2 & 6 & 25 \\
Cost 6 & 1 & 2 & 6 & 10 \\
Cost 7 & 3 & 1 & 5 & 25 \\
Cost 8 & 2 & 1 & 5 & 20 \\
Cost 9 & 2 & 1 & 6 & 25 \\
Cost 10 & 3 & 1 & 5 & 20 \\
Cost 11 & 3 & 1 & 5 & 30 \\
Cost 12 & 3 & 1 & 5 & 15 \\
Cost 13 & 1 & 1 & 5 & 15 \\
Cost 14 & 5 & 1 & 5 & 20 \\
Cost 15 & 5 & 1 & 5 & 1 \\
Cost 16 & 5 & 1 & 1 & 20 \\
\hline
\end{tabular}

${ }^{a}$ In scenarios 3 and 4 , the riparian not only included those areas identified as "riparian" in the vegetation map, but also the waterways depicted in the streams GIS layer

created additional hypotheses. PA mountain beavers are thought to use riparian areas in the interior, forested portion of their range (Billig and Douglas 2007, R. Douglas, Mendocino Redwood Company, pers. comm.), thus in 7 of the 16 models we assigned the lowest resistance values to Riparian. In two of these 7 models we considered Riparian to be both the areas classified as riparian in the vegetation coverage (i.e., Montane Riparian and Valley Foothill Riparian vegetation types) and the waterways in the statewide hydrology stream coverage. We did this because linear shaped features, such as riparian zones, are often misclassified or overlooked during initial vegetation classification (McKelvey and Noon 2001). We parameterized Forest and Grass/Shrub/Forb with resistance values that varied from 1-5 and 1-6, respectively. Grass/Shrub/Forb was assigned slightly higher resistance values because the presence of grasses has been negatively related to habitat use or den site selection (Hacker and Coblentz 1993).

All other landscape features were classified as NonHabitat using resistance values ranging from 1 to 30 . The extremely low values for Non-Habitat were included to test the logic of our assumption that these are inhospitable cover types. If this assumption is correct, low values should not yield supported models. We ran least cost path analyses among all pairs of individuals, informed by each of the resistance scenarios, using the function COSTDISTANCE in ArcGIS (ESRI 2003). We also explored the effect of sample size per site on the results by using only those sites with three or more individuals $(n=9)$ and sites with nine or more individuals $(n=6)$.

The null hypothesis of isolation by distance is characterized by the relationship between pair-wise genetic distances and the logarithm of geographic distances (Rousset 2000). This relationship was tested via matrix regression and using partial Mantel tests. Partial Mantel tests were used to test for the effects of landscape features, when controlling for geographic distance, and vice versa.

\section{Results}

Microsatellite variation

A total of 1,353 samples were collected (55 tissues, 1,295 hair samples and three samples from bone). We obtained complete genotypes for the 55 tissues. Only 373 (28.8\%) of the hair samples produced completed genotypes, although this was probably due to the initial inclusion of hairs from non-target species in the sample pool (for example, in a pilot study of 20 hair samples sequenced using the cytochrome B region to identify species, nine (45\%) were from brush rabbit [Sylvilagus bachmani]). We were also able to successfully genotype two of three of the bone samples $(66.7 \%)$. In total, we were able to identify 141 unique individual PA mountain beavers. Of these, 84 $(59.6 \%)$ were solely identified using samples from hair snares, $55(39.0 \%)$ were identified from tissue samples and two individuals were identified from bone (skull) samples.

Most of the samples came from the study sites in Manchester State Park (Kinney Beach and Alder Creek; see Zielinski et al. in review) and the majority of the samples from outside the park were in the central and southern portion of the geographic range (Table 1; Fig. 1). Sex ratios were relatively even in most locations (Table 1).

Treating the entire sample as one population, we found 48 distinct alleles (average $=3.69$ per locus, range $2-7$ ) and allele frequencies that showed significant deviations from Hardy-Weinberg proportions at 7 of 13 loci (A1, A114, B8, C3, ArA08F, ArH04F, and ArG05F) suggesting the existence of population subdivision. Global tests for heterozygosity deficits were significant $(P<0.0001)$ and the global $\mathrm{F}_{\mathrm{IS}}$ was 0.208 . When we divided the sample into the 17 sites, only the Kinney Beach site was out of Hardy-Weinberg proportions, driven by deviations at locus $A l$ and $C 3\left(\mathrm{~F}_{\mathrm{IS}}\right.$ 0.301 and $0.069, P=0.0058$ and 0.0064 , respectively). Pairwise $\mathrm{F}_{\mathrm{ST}}$ among the sites ranged from 0.047 to 0.499 (Table 4), while a global $\mathrm{F}_{\mathrm{ST}}$ was $0.226(\mathrm{SE}=0.031)$. Rerunning the analysis with only those 9 PA mountain beaver sites with $>3$ individuals still yielded all 48 alleles from the full dataset. The global $\mathrm{F}_{\mathrm{ST}}$ in this subset analysis was $0.229(\mathrm{SE}=0.032)$. Pairwise $\mathrm{F}_{\mathrm{ST}}$ among these sites 


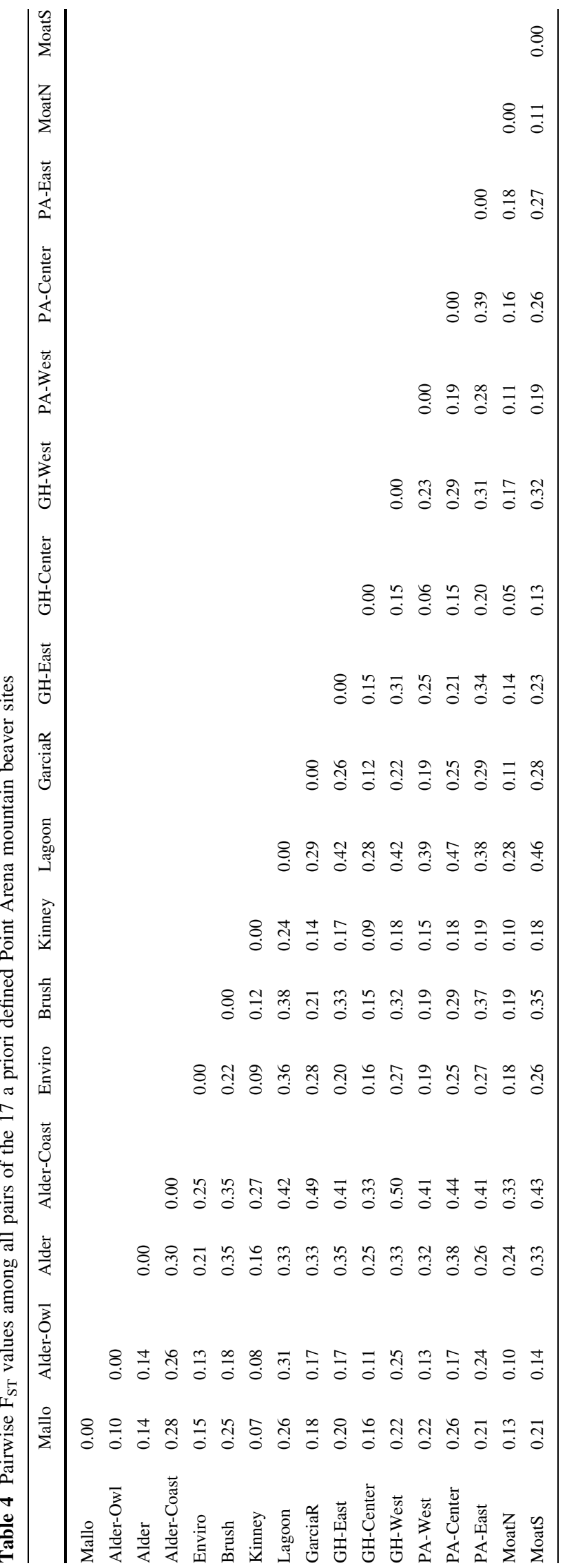

ranged from 0.02 to 0.483 . Lastly, considering only those sites with $\geq 9$ individuals ( $n=6$; Mallo, Alder, Kinney, GarciaR, GH-Center, MoatN), all 48 known alleles were again found and global $F_{\mathrm{ST}}$ was $0.241(\mathrm{SE}=0.034)$. Pairwise $\mathrm{F}_{\mathrm{ST}}$ among these groups ranged from 0.06 (GH-Center to MoatN) to 0.475 (Alder to GarciaR).

Considering all individuals separately, the first two axes in the principal coordinates analysis explained $54.6 \%$ of the variation (axis 1: $36.9 \%$, axis 2: $17.7 \%$; Fig. 3 ). There was no conspicuous clustering of samples into groups at this level of analysis, although some individuals appeared to aggregate (e.g., the Alder Creek individuals and the Garcia River individuals). When we conducted the PCA clustering based on the 17 sites, they were best described by two significant axes which accounted for $64.2 \%$ of the variation. Most of the southern and interior sites clustered and were separate from the Alder site group and a cluster that included the Kinney, Brush and Enviro sites (Fig. 4).

Considering our STRUCTURE analysis, a total of 120 individuals had $Q$ values that exceeded 0.74 (a natural break in the distribution of $Q$ values) and, thus, could be assigned to a group. The most supported number of groups (k) was 3, based on the inflection point of the function that relates variance reduction to number of groups (Figure S1; Supplemental Material). This was confirmed with graphical output (Fig. S2; Supplemental Material). The 3 groups included: (1) a "Southern and Interior" group composed of individuals from Moat Creek, Point Arena Creek, GarciaHathaway Creek, and the Garcia River watersheds but also including Mallo Pass and Alder/Owl Creek watersheds in the north; (2) a "Central" group that consists largely of the Kinney Beach individuals in the Brush Creek watershed; and (3) a "Northern Coastal" group that consists largely of the individuals at the Alder Creek site. There was no clear pattern of relationship of group to vegetation type, nor to watershed (Fig. 2a, b). Most notably, there was no segregation of genotypes by distance from the coast. Nearcoastal sites, which are most often dominated by non-forest types, were not always in the same groups (note Alder and Kinney, for example). However, many of the interior sites, which were typically in forested areas, tended to be in the same group regardless of their watershed (Fig. 2b).

When we calculated $\mathrm{F}_{\mathrm{ST}}$ among STRUCTURE groups and produced an average $\mathrm{F}_{\mathrm{ST}}$ per population, the Northern Coastal group had a distinctly higher $\mathrm{F}_{\mathrm{ST}}$ value (0.56) than the other groups and also had the higher values for pairwise $\mathrm{F}_{\mathrm{ST}}$ values (Table 5).

Mitochondrial variation

We amplified a 444 bp fragment of the control region in 85 individuals. There were six variable sites in this region; all were substitutions ( 5 transitions and 1 transversion) and no 
Fig. 3 Results of principal coordinates analysis for all 141 individuals, represented by symbols that correspond to the PA mountain beaver site where they were collected
Fig. 4 Results of principal coordinates analysis for the 17 PA mountain beaver sites. Ellipses enclose the group they were assigned by program STRUCTURE (far right $=$ Northern Coastal; lower left $=$ Central; upper left $=$ Southern and Interior)

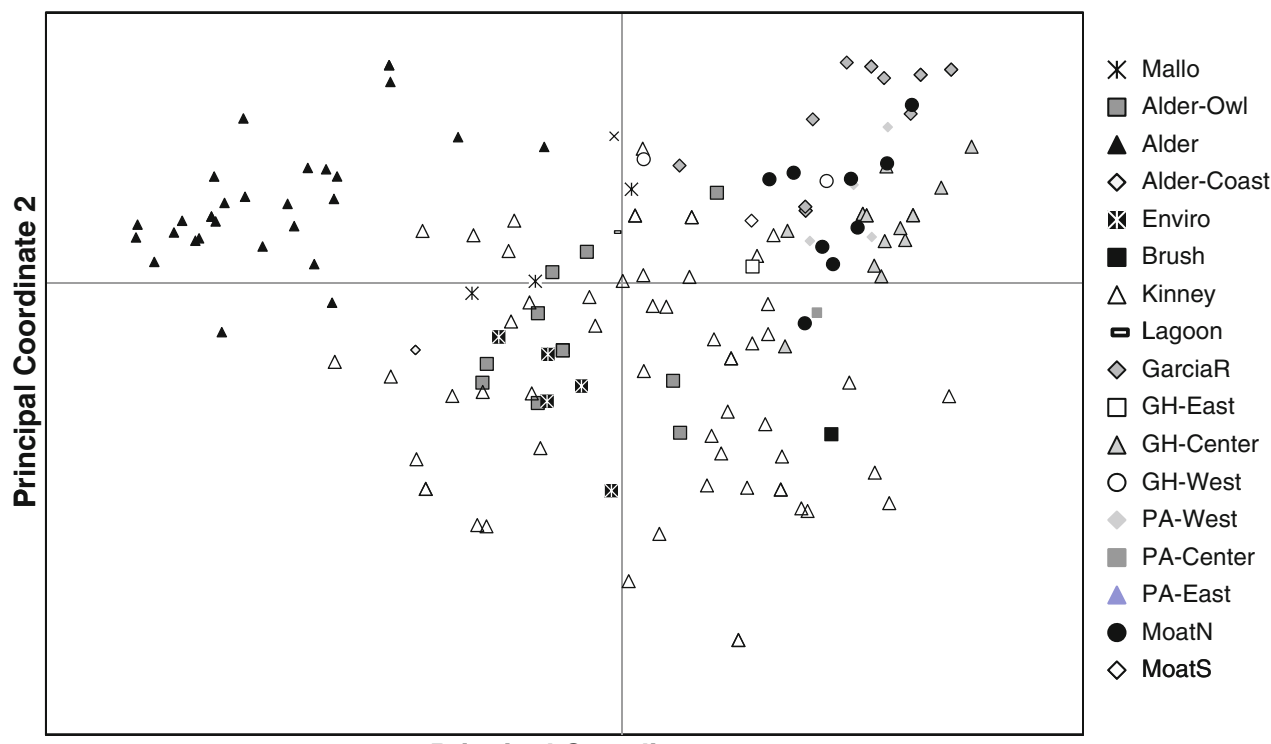

Principal Coordinate 1

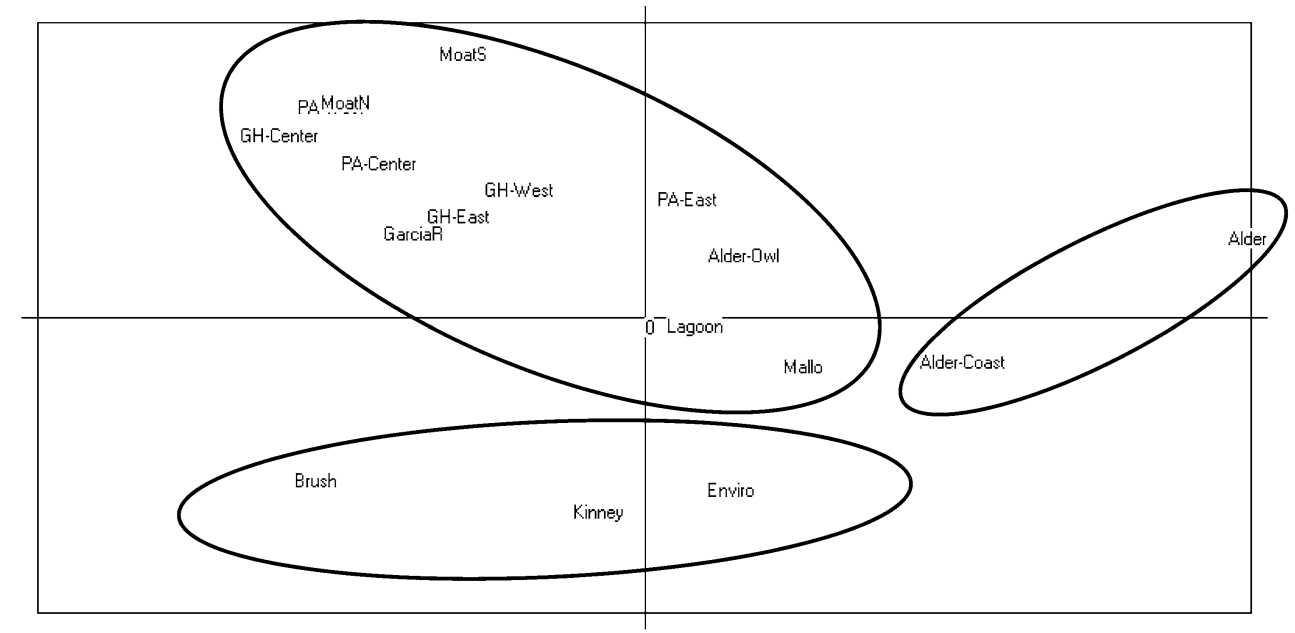

Table 5 Pairwise $F_{\text {ST }}$ values among the 3 groups identified by program STRUCTURE, as well as mean $\mathrm{F}_{\mathrm{ST}}$ values for each Point Arena mountain beaver group

\begin{tabular}{llll}
\hline & Central & $\begin{array}{l}\text { Southern } \\
\text { and Interior }\end{array}$ & $\begin{array}{l}\text { Northern } \\
\text { Coastal }\end{array}$ \\
\hline Central & 0.000 & & \\
Southern and Interior & 0.075 & 0.000 & \\
$\begin{array}{l}\text { Northern Coastal } \\
\text { Mean F }\end{array}$ & 0.166 & 0.216 & 0.000 \\
\hline
\end{tabular}

insertions or deletions were detected (Table 6). Two haplotypes were identified: PAMB-A and PAMB-B (GenBank accession nos. JX413593 and JX413594). Haplotype B was most common (in 73 individuals) and was detected in 13 of the 17 sampling sites (Table 6) and in the 3 groups identified by the STRUCTURE analysis. Haplotype A (in 12 individuals) was only detected in 6 sites, all south of the Garcia River. Both haplotypes were detected in 2 of the sites: GH-Center and GH-West. Haplotype A was not found north of the Garcia River. We are confident in this result after estimating that we had a $95 \%$ chance of detecting this haplotype north of the river if it occurred there with a $5 \%$ frequency, and a $68 \%$ chance of detecting it if it occurred there with $2 \%$ frequency.

\section{Effective population size and bottlenecks}

We estimated $\mathrm{N}_{\mathrm{e}}$ at the 6 sites with $\geq 9$ individuals and in the 3 groups identified by program STRUCTURE $(n=120$, as only those individuals that assigned to a cluster with a $Q>0.74$ were included). $\mathrm{N}_{\mathrm{e}}$ estimates were between 5.4 
Table 6 Variable nucleotide sites within the left hypervariable domain of the control region for each of the two haplotypes. The nucleotide positions are numbered relative to the first nucleotide using primer L2 and consist of 444 base pairs. Table also includes the distribution of haplotypes among the 17 Point Arena mountain beaver (PAMB) sites

\begin{tabular}{|c|c|c|c|c|c|c|c|c|c|}
\hline \multirow[t]{2}{*}{ Haplotype } & \multirow[t]{2}{*}{70} & \multirow[t]{2}{*}{164} & \multirow[t]{2}{*}{187} & \multirow[t]{2}{*}{211} & \multirow[t]{2}{*}{335} & \multirow[t]{2}{*}{351} & \multirow[t]{2}{*}{ PAMB site } & \multicolumn{2}{|c|}{ Haplotype } \\
\hline & & & & & & & & A & B \\
\hline A & A & A & $\mathrm{C}$ & $\mathrm{C}$ & $\mathrm{T}$ & G & Mallo & & 2 \\
\hline \multirow[t]{17}{*}{ B } & G & G & $\mathrm{T}$ & $\mathrm{T}$ & A & A & Alder-Owl & & 7 \\
\hline & & & & & & & Alder & & 14 \\
\hline & & & & & & & Alder-Coast & & 1 \\
\hline & & & & & & & Enviro & & 7 \\
\hline & & & & & & & Brush & & 1 \\
\hline & & & & & & & Kinney & & 24 \\
\hline & & & & & & & Lagoon & & 1 \\
\hline & & & & & & & GarciaR & 3 & \\
\hline & & & & & & & GH-East & 1 & \\
\hline & & & & & & & GH-Center & 4 & 11 \\
\hline & & & & & & & GH-West & 1 & 1 \\
\hline & & & & & & & PA-West & & 2 \\
\hline & & & & & & & PA-Center & & 1 \\
\hline & & & & & & & PA-East & 1 & \\
\hline & & & & & & & MoatN & 2 & \\
\hline & & & & & & & MoatS & & 1 \\
\hline & & & & & & & Total & 12 & 73 \\
\hline
\end{tabular}

(GH-Central) and 11.7 (Alder) when random mating was assumed, and excluding estimates for which an upper $95 \%$ confidence interval could be not be achieved (Table 7). Using the STRUCTURE groupings produced estimates of 11.7 for the Northern Coastal group, 15.8 for the Central and 27.7 for the Southern and Interior group (Table 7). Grouping by simply geography (i.e., north of Alder, north of Garcia and south of Alder, and south of Garcia) resulted in similar $\mathrm{N}_{\mathrm{e}}$ estimates, except they were substantially smaller for the region north of Alder Creek (Table 7). All estimates under the monogamy mating assumption were nearly double that of the random mating simulations.

The bottleneck test results were consistent with the small effective population size estimates; Wilcoxon tests were significant for the Central, Northern Coast, and the Southern and Interior STRUCTURE groups $(P=0.00006, P=$ 0.00978 , and $P=0.01331$, respectively). The mode-shift test identified a bottleneck in the Central and Northern Coastal groups. The Wilcoxon results from each of the 6 a priori populations with adequate sample size detected bottlenecks in the Alder, Kinney, and the GH-Center sites $(P=0.013, P=0.00006$, and $P=0.04$, respectively). There was a mode shift detected in each of the 3 groups as well.

Gene flow and landscape features

Our landscape genetic analysis, which focused on the 17 PA mountain beaver sites, showed that geographic distance did not explain genetic distance $(r=0.11, P=0.10)$, suggesting that gene flow was better explained by some factor other than simply the distance between samples. All of our least cost-path models were significant and all but three of those models (models 2, 3, and 4) remained significant even after controlling for Euclidean (geographic) distance, indicating that landscape vegetation configuration was an important predictor of gene flow (Table 8). None of the models comparing genetic distance against geographic (Euclidean) distance were significant when accounting for the least-cost paths (Table 8). Although geographic distance was non-significant on its own $(P=0.07)$ our statistical results suggest that it did explain some of the genetic variation. Using only those PA mountain beaver sites with $>3$ individuals (Table S1; Supplemental Material) and 9 or more individuals (Table S2; Supplemental Material) produced similar patterns, but with stronger
Table 7 Estimates of effective population size $\left(\mathrm{N}_{\mathrm{e}}\right)$ for the 6 Point Arena mountain beaver sites with adequate sample sizes, by geographic area (North, Central and South), and again for the 3 groups (Northern Coastal, Central, and Southern and Interior) identified by program STRUCTURE. Estimates of effective population size were calculated using LDNE (Waples and Do 2008) using only alleles at a frequency of 0.05 or greater and under 2 different mating models: random and monogamy

\begin{tabular}{lccc}
\hline PAMB site & Sample size & \multicolumn{2}{c}{ Effective population size (95 \% CI) } \\
\cline { 3 - 4 } & & Random mating & Monogamy \\
\hline Alder-Owl & 10 & $7(2.2-55.8)$ & $16(5.3-113.2)$ \\
Alder & 27 & $11.7(2.9-65.6)$ & $25.1(8.8-133.0)$ \\
Kinney Beach & 51 & $7.7(3.9-11.9)$ & $18(12.2-25.8)$ \\
Garcia River & 10 & $2.9(1.1-\infty)$ & $8.8(2.2-\infty)$ \\
Garcia-Hathaway (Center) & 13 & $5.4(2.3-15.2)$ & $13.3(6.0-32.1)$ \\
Moat (North) & 9 & $42.8(3.1-\infty)$ & $87.3(9.7-\infty)$ \\
Sampled North of Alder & 41 & $3.0(2.2-3.9)$ & $7.7(4.5-12.2)$ \\
Sampled North of Garcia and South of Alder & 58 & $12.0(8.0-17.6)$ & $26.0(18.4-36.9)$ \\
Sampled South of Garcia & 42 & $37.3(24.2-147.6)$ & $94.5(50.1-296.7)$ \\
STRUCTURE Group 1 Central & 53 & $15.8(10.3-24.3)$ & $33.4(22.7-50.4)$ \\
STRUCTURE Group 2 Northern Coastal & 27 & $11.7(2.9-65.6)$ & $25.1(8.8-133.0)$ \\
STRUCTURE Group 3 Southern and Interior & 40 & $27.7(16.2-56.8)$ & $57.1(34.2-115.0)$ \\
\hline
\end{tabular}


Table 8 Results of matrix regression in explaining genetic distance for all Point Arena mountain beaver sites $(n=17)$. Values are partial Mantel $r$ values ( $P$ value); ns indicates a $P$ value $>0.05$

\begin{tabular}{lllll}
\hline Scenario & $\begin{array}{l}\text { Geographic } \\
\text { distance }\end{array}$ & $\begin{array}{l}\text { LCP } \\
\text { distance }\end{array}$ & $\begin{array}{l}\text { LCP distance } \\
\text { (partial Mantel } r \text { ) }\end{array}$ & $\begin{array}{l}\text { Geographic distance } \\
\text { (partial Mantel } r \text { ) }\end{array}$ \\
\hline Cost 1 & ns & $0.04(0.05)$ & $0.35(0.01)$ & $\mathrm{ns}$ \\
Cost 2 & $\mathrm{~ns}$ & $\mathrm{~ns}$ & $\mathrm{~ns}$ & $\mathrm{~ns}$ \\
Cost 3 & $\mathrm{~ns}$ & $\mathrm{~ns}$ & $\mathrm{~ns}$ & $\mathrm{~ns}$ \\
Cost 4 & $\mathrm{~ns}$ & $\mathrm{~ns}$ & $\mathrm{~ns}$ & $\mathrm{~ns}$ \\
Cost 5 & $\mathrm{~ns}$ & $0.07(0.02)$ & $0.36(0.016)$ & $\mathrm{ns}$ \\
Cost 6 & $\mathrm{~ns}$ & $0.07(0.03)$ & $0.37(0.06)$ & $\mathrm{ns}$ \\
Cost 7 & $\mathrm{~ns}$ & $0.13(0.001)$ & $0.40(0.023)$ & $\mathrm{ns}$ \\
Cost 8 & $\mathrm{~ns}$ & $0.12(0.002)$ & $0.38(0.017)$ & $\mathrm{ns}$ \\
Cost 9 & $\mathrm{~ns}$ & $0.13(0.001)$ & $0.38(0.022)$ & $\mathrm{ns}$ \\
Cost 10 & $\mathrm{~ns}$ & $0.13(0.002)$ & $0.40(0.016)$ & $\mathrm{ns}$ \\
Cost 11 & $\mathrm{~ns}$ & $0.13(0.003)$ & $0.40(0.013)$ & $\mathrm{ns}$ \\
Cost 12 & $\mathrm{~ns}$ & $0.13(0.002)$ & $0.40(0.02)$ & $\mathrm{ns}$ \\
Cost 13 & $\mathrm{~ns}$ & $0.10(0.003)$ & $0.34(0.035)$ & $\mathrm{ns}$ \\
Cost 14 & $\mathrm{~ns}$ & $0.14(0.004)$ & $0.40(0.02)$ & $\mathrm{ns}$ \\
Cost 15 & $\mathrm{~ns}$ & $0.06(0.05)$ & $0.32(0.03)$ & $\mathrm{ns}$ \\
Cost 16 & $\mathrm{~ns}$ & $0.03(0.07)$ & $0.38(0.03)$ & $\mathrm{ns}$ \\
\hline
\end{tabular}

correlations between least cost-path matrices and genetic distances. In all of the best supported models we specified high resistance for what was classified as Non-habitat, low resistance for Forest, and intermediate resistance for Grass/ Shrub/Forbs and for Riparian. The most supported model (Cost 14) had Forests with a resistance $=1$, Riparian and Grass/Shrub/Forbs with a resistance $=5$, and Non-Habitat with a resistance $=20(r=0.44, P=0.03$; partial mantel $r=0.62, P=0.07)$. A number of other models fit the data nearly as well (Table S2; Supplemental Material), but most of these (i.e., Cost 7, 8, 10, 11, 12, 15) also specified Forests as having the lowest resistance value (i.e., 1). Thus, the distribution of genotypes within the geographic range suggests that Point Arena mountain beavers move through forest vegetation types more easily than other vegetation types or along riparian areas.

\section{Discussion}

Measures of contemporary and historical gene flow demonstrate significant structure in the small and isolated distribution of the Point Arena mountain beaver. The contemporary genetic structure appears mediated by differential gene flow affected by landscape configuration. We identified 3 genetic groups from our nuclear data samples: Northern Coastal, Central, and Southern and Interior. These are potentially important subdivisions within the subspecies and should be considered in future management decisions. Among the 3 groups, however, North Coastal, which primarily represents a small area on a bluff overlooking Alder Creek, was differentiated from others by its substantially higher $\mathrm{F}_{\mathrm{ST}}$ value $\left(\mathrm{STRUCTURE} \mathrm{F}_{\mathrm{ST}}=0.56\right)$ and higher $\mathrm{F}_{\mathrm{ST}}$ values when compared directly with other sites (Table 4).

Samples were not always easy to classify; 21 of the 141 samples (14.9\%) did not meet the threshold for assignment to any of the 3 groups. Thus, individual mountain beavers could not always be categorized as belonging to one of the multilocus groups. However, all of the individuals from the North Coast group assigned to this group, unlike members of the other 2 multilocus groups. Thus, there appears to be strong isolation between the animals that occupy the North Coast group compared to the individuals in other groups. The Alder Creek population is also very small; estimated to be less than 25 individuals (Zielinski et al. in review) and with an estimated effective population size of 11 . These are very low numbers, characterized by some standards as representing a population in the most urgent need of conservation measures (i.e., "Critical" by Mace and Lande (1991) standards, for example).

Effective population sizes were small for all sites and all groups regardless of how we partitioned the samples, suggesting that they are all likely to experience the negative effects of genetic drift without additional gene flow (Lande 1994). The point estimates of $\mathrm{N}_{\mathrm{e}}$ for almost all of the sites and groups are $<50$, which suggests that they are at risk of loss of evolutionary potential and inbreeding (Franklin 1980). Many of the sites are isolated small populations, some of which may be comprised of family members. Particularly troubling are the relatively low effective population sizes for each of the 3 genetic groups identified by program STRUCTURE (range in estimates: 15-57; Table 7) and the low effective population sizes for 
each of the 3 genetic groups using the geographic breaks identified with STRUCTURE (but including all individuals; Table 7). These low $\mathrm{N}_{\mathrm{e}}$ estimates combined with the significant Fst results suggests isolation with high levels of genetic drift.

The mtDNA data are intriguing, given that there are only 2 haplotypes and they are differentially distributed relative to the Garcia River. It is possible that this river was a barrier to movement and that genetic drift has eliminated haplotype A from north of the river. Alternatively, given that each haplotype is based on multiple substitutions, each may have evolved in independent refugia with unidirectional movement of only one of the haplotypes when they moved from these refugia. Piaggio et al. (unpubl. data) explored the phylogenetics of the mountain beaver using mtDNA variation and included samples from 8 of our individuals in their analysis. Among these they found a single cyt $b$ haplotype and confirmed one of two of our CR haplotypes (our haplotype B). Piaggio et al. (unpubl. data) confirmed the veracity of A. r. nigra as a distinct, wellsupported clade. They also explored potential geographic barriers among the adjacent distributions of 4 mountain beaver subspecies in the Pacific Northwest and agreed with Gyug (2000) that large rivers may serve as barriers (e.g., Fraser River, Columbia River). The Garcia River is small by these standards, but may also have provided resistance to flow of individuals of haplotype $\mathrm{A}$ at some time in the past.

We suggest that each of the 3 genetic groups identified from the nuclear data analysis, and the 2 regions with distinct haplotype distributions may qualify as what Moritz (1994) defined as "management units"; populations that have diverged and are connected by such low levels of gene flow that they are functionally independent. Management units are a logical entity for population monitoring and demographic studies (Moritz 1994). Our results suggest that the group for which management status may be most justified is the Northern Coastal group (i.e., the Alder Creek population) because this group has lower microsatellite variation, is more isolated and occurs north of the Garcia River where there is a single haplotype represented. This population has, in fact, been the subject of annual population estimation and monitoring from 2006 to 2009 (Zielinski et al. in review). Based on the results reported here, we recommend that this monitoring continue.

Our landscape genetics data revealed that gene flow in the Point Arena mountain beaver was better explained by landscape vegetation features than by geographic distance. Gene flow was predictably poor through areas we defined as Non-Habitat (i.e., Crops/Agriculture, Estaurine, Lacustrine, Urban). Most of the Non-Habitat types were pasture or other agricultural lands where we find very few PA mountain beaver burrows and expected very little movement. The genetic evidence suggests that Forest was the most permeable cover type. The intermediate permeability values for the Grass/Shrub/Forb type were expected, given that it includes grasslands, which are a relatively unique habitat type for mountain beavers (Feldhamer et al. 2003). However, that Riparian was not the most permeable type was a surprise since mountain beavers are associated with areas near available water (Feldhamer et al. 2003; Nungesser and Pfeiffer 1965) and we expected that riparian areas provide the most likely corridors for movements and dispersal (as presumed for other species of burrow-dwelling mammals; e.g., Roach et al. 2001). PA mountain beavers may be more amenable to cross-country travel through forest environments than we originally suspected. Perhaps this should be expected, given that throughout much of their range mountain beavers occupy openings in forests (Hacker and Coblentz 1993; Feldhamer et al. 2003). These openings become less suitable as they succeed to closed canopy conditions, presumably forcing the occupants to search for other, newly created openings. Thus, mountain beaver life histories may include a dispersal phase that requires them to move through forests to find suitable habitat. Indeed, mountain beavers have been reported to move relatively long distances above ground, sometimes in excess of $300 \mathrm{~m}$ (Arjo et al. 2007; Lovejoy and Black 1979).

We suspect that future studies of landscape genetics would benefit from including site-specific information about soil characteristics since this burrowing mammal is presumably distributed on the basis of soil depth, soil porosity and soil water-holding capacity (Beier 1989; Feldhamer et al. 2003). The current soil map for the range of the PA mountain beaver has relatively large polygons, the boundaries of which were often described on the basis of vegetation boundaries (http://www.ca.nrcs.usda.gov/mlra02/wmendo/ index.html). Thus, we did not view it as a useful predictor of gene flow given that vegetation type was already included in our analysis. It is interesting to note, however, that two of the most distinct genetic nuclear DNA groups, the Northern Coastal group and the Central group, occur on the same soil type: Crispin Loam. Sampling soil characteristics at occupied burrow locations will be an important next step to understanding the full complement of features that may affect gene flow, as well as habitat selection in general.

Genetic analysis confirms that the PA mountain beaver is a taxon that continues to be vulnerable to the loss of additional populations. $\mathrm{F}_{\mathrm{ST}}$ values are relatively high, indicating considerable population subdivision and relatively low gene flow among sites. In addition, effective population sizes are low and most sites have experienced a significant population bottleneck in their past. For a metapopulation with these characteristics to persist, the risk of loss of these small populations must be counterbalanced 
by adequate migration and recolonization, similar to that described for metapopulations of other burrowing rodents (e.g., Roach et al. 2001). Thus, human activities that limit dispersal among sites could disrupt this equilibrium. Because our landscape genetics analysis indicates that PA mountain beavers appear to move most readily through forests, activity that limits or fragments forest may be detrimental to the processes that maintain the extinction and colonization dynamics operating in this taxon. However, we expect that a significant amount of forest cover would need to be removed before this would occur, particularly since openings in forest created by natural or anthropogenic disturbance can provide important breeding habitat as well. Our results are based on the indirect inferences from the pattern of gene flow; it will also be important to study how individual Point Arena mountain beavers move through forest and non-forest habitats directly. Data describing the population dynamics within each of the genetic groups would also be useful. Such data will help us understand ecological factors that affect spatial phenomena that are not captured by genetic information alone.

Acknowledgments We gratefully acknowledge the financial support of the Arcata office of the US Fish and Wildlife Service and the assistance of Robin Hamlin and John Hunter. The Pacific Southwest Research Station, USDA Forest Service, also contributed financial support for this study. Renee Pasquinelli (California Department of Parks and Recreation) provided administrative support. We appreciate the field assistance of Angela Liebenberg, Robert Douglas, Nina A. Nahvi, and Skylar C. Giordano. Kaytee Redfern helped in the laboratory and Janet Werren assisted with developing figures. Access to land was facilitated by Marty Hillscan and William Marshall (City of Point Arena), Matt Matijczyk (Point Arena Tileworks), Denise and Andy Fisher, the McConnell family, Steve Miller and the Mendocino Redwood Company. We thank John Hunter for edits on an earlier version of the manuscript. The research was authorized under Federal Fish and Wildlife Permit \#TE080774-3 and California state permit \#801091-04.

\section{References}

Arjo WM, Huenefeld RE et al (2007) Mountain beaver home ranges, habitat use, and population dynamics in Washington. Can J Zool 85:328-337

Beier P (1989) Use of habitat by mountain beaver in the Sierra Nevada. J Wildl Manag 53:649-654

Billig SC, Douglas RB (2007) Habitat characteristics and spatial extent of burrow systems of Point Arena mountain beavers on managed timberlands. In: Standiford RB, Giusti GA, Valachovic Y, Zielinski WJ, Furniss MJ (eds) Proceedings of the Redwood Region Forest Science Symposium: what does the future hold? USDA Forest Service General Technical Report GTR-PSW-194. Pacific Southwest Research Station, Albany, pp 491-492

Broquet T, Ray N, Petit E, Fryxell JM, Burel F (2006) Genetic isolation by distance and landscape connectivity in the American marten (Martes americana). Land Ecol 21:877-889
Camp CL (1918) Excavations of burrows of the rodent Aplodontia, with observations on the habits of the animal. Univ Calif Publ Zool 17:517-536

Cornuet JM, Luikart G (1996) Description and power analysis of two tests for detecting recent population bottlenecks from allele frequency data. Genetics 144:2001-2014

Coulon A, Cosson JF, Angibault JM, Cargnelutti B, Galan M, Morellet N, Petit E, Aulagnier S, Hewison JM (2004) Landscape connectivity influences gene flow in a roe deer population inhabiting a fragmented landscape: an individual-based approach. Mol Ecol 13:2841-2850

Environmental Systems Research Institute (ESRI) (2003) ARC/INFO user's guide. Environmental Systems Research Institute, Redlands

Epps CW, Wehausen JD, Bleich VC, Torres SG, Brashares JS (2007) Optimizing dispersal and corridor models using landscape genetics. J Appl Ecol 44:714-724

Falush D, Stephens M, Pritchard JK (2007) Inference of population structure using multilocus genotype data: dominant markers and null alleles. Mol Ecol Notes 7:574-578

Feldhamer GA, Rochelle JA, Rushton CD (2003) Mountain beaver (Aplodontia rufa). In: Feldhamer GA, Thompson BC, Chapman JA (eds) Wild mammals of North America: biology, management, and conservation. Johns Hopkins, Baltimore, pp 179-187

Franklin IR (1980) Evolutionary change in small populations. In: Soule ME, Wilcox BA (eds) Conservation biology: an evolutionary-ecological perspective. Sinauer, Sunderland, pp 135-150

García-Muro E, Aznar MP, Rodellar C, Zaragoza P (1997) Sex specific PCR/RFLPs in the canine ZFY/ZFX loci. Anim Genet 28:150-158

Goudet J (1999) PCAGEN ver. 1. 2. Population Genetics Laboratory, University of Lausanne, Lausanne

Goudet J (2001) FSTAT, a program to estimate and test gene diversities and fixation indices, version 2.9.3. URL:http://www2. unil.ch/popgen/softwares/fstat.htm. Accessed 7 Dec 2011

Gyug LW (2000) Status, distribution, and biology of the mountain beaver, Aplodontia rufa, in Canada. Can Field Nat 114:476-490

Hacker AL, Coblentz BE (1993) Habitat selection by mountain beavers recolonizing Oregon coast range clearcuts. J Wildl Manag 57:847-853

Hall ER (1981) The mammals of North America, 2nd edn. Wiley, New York

Kocher TD, Thomas WK, Meyer A, Edwards SV, Pääbo S, Villablanca FX, Wilson AC (1989) Dynamics of mitochondrial DNA evolution in animals: amplification and sequencing with conserved primers. Proc Natl Acad Sci USA 86:6196-6200

Lande R (1994) Risk of population extinction from fixation of new deleterious mutations. Evolution 48:1460-1469

Lovejoy BP, Black HC (1979) Population analysis of the mountain beaver, Aplodontia rufa pacifica, in western Oregon. Northwest Sci 53:82-89

Luikart G, Cornuet JM, Allendorf FW (1999) Temporal changes in allele frequencies provide estimates of population bottleneck size. Conserv Biol 13:523-530

Mace GM, Lande R (1991) Assessing extinction threats: toward a reevaluation of IUCN threatened species categories. Conserv Biol 5:148-157

Manel S, Schwartz MK, Luikart G, Taberlet P (2003) Landscape genetics: combining landscape ecology and population genetics. Trends Ecol Evol 18:189-197

McDevitt AD, Mariani S, Hebblewhite M, Decesare NJ, Morgantini LE, Seip D, Weckworth B, Musiani M (2009) Survival in the Rockies of an endangered hybrid swarm from diverged caribou (Rangifer tarandus) lineages. Mol Ecol 18:665-679

McKelvey KS, Noon BR (2001) Incorporating uncertainties in animal location and map classification into habitat relationships 
modeling. In: Hunsaker CT, Goodchild MF, Friedl MA, Case TJ (eds) Spatial uncertainty in ecology. Springer, New York, pp 72-90

McKelvey KS, Schwartz MK (2005) Dropout: a program to identify problem loci and samples for noninvasive genetic samples in a capture-mark-recapture framework. Mol Ecol 5:716-718

Moritz C (1994) Applications of mitochondrial DNA analysis in conservation: a critical review. Mol Ecol 3:401-411

Nungesser WC, Pfeiffer EW (1965) Water balance and maximum concentrating capacity in the primitive rodent, Aplodontia rufa. Comp Physiol Biochem 14:289-297

Palstra FP, Ruzzante DE (2008) Genetic estimates of contemporary effective population size: what can they tell us about the importance of genetic stochasticity for wild population persistence? Mol Ecol 17:3428-3447

Paxinos E, McIntosh C, Ralls K, Fleischer R (1997) A noninvasive method for distinguishing among canid species: amplification and enzyme restriction of DNA from dung. Mol Ecol 6:483-486

Peakall R, Smouse PE (2006) GENALEX 6: genetic analysis in Excel: population genetic software for teaching and research. Mol Ecol Notes 6:288-295

Piaggio AJ, Meubaum MA, Yueh H, Ritland CE, Johnston JJ, Perkins SL (2009) Development of 10 polymorphic microsatellite loci isolated from the mountain beaver, Aplodontia rufa rufa (Rafinesque). Mol Ecol Resour 9:323-325

Pilgrim KL, Zielinski WJ, Mazurek MJ, Schlexer FV, Schwartz MK (2006) Development and characterization of microsatellite markers in the Point Arena mountain beaver Aplodontia rufa nigra. Mol Ecol Notes 6:800-802

Pilgrim KL, Zielinski WJ, Schlexer FV, Schwartz MK (2012) Development of a reliable method for determining sex for a primitive rodent, the Point Arena mountain beaver (Aplodontia rufa nigra). Con Gen Res. doi:10.1007/s12686-012-9686-6

Piry S, Luikart G, Cornuet J (1999) BOTTLENECK: a computer program for detecting recent reductions in the effective population size using allele frequency data. J Hered 90:502-503

Pritchard JK, Stephens M, Donnelly P (2000) Inference of population structure using multilocus genotype data. Genetics 155:945-959

Raymond M, Rousset F (1995) GENEPOP (version 1.2): population genetics software for exact tests and ecumenicism. J Hered 86:248-249

Roach JL, Stapp P, Van Horne B, Antolin MF (2001) Genetic structure of a metapopulation of black-tailed prairie dogs. J Mammal 82:946-959

Rosenberg NA (2004) DISTRUCT: a program for the graphical display of population structure. Mol Ecol Notes 4:137-138

Rousset F (2000) Genetic differentiation between individuals. J Evol Biol 13:58-62
Rousset F (2008) GENEPOP'007: a complete re-implementation of the GENEPOP software for Windows and Linux. Mol Ecol Resour 8:103-106

Schwartz MK, Cushman SA, McKelvey KS, Hayden J, Engkjer C (2006) Detecting genotyping errors and describing black bear movement in North Idaho. Ursus 17:138-148

Shields GF, Kocher TD (1991) Phylogenetic relationships of North American ursids based on analysis of mitochondrial DNA. Evolution 45:218-221

Steele D, Litman L (1998) Point Arena mountain beaver (Aplodontia rufa nigra) recovery plan. Region 1, U.S. Fish and Wildlife Service, Portland

Taylor W (1918) Revision of the rodent genus Aplodontia. Univ Calif Publ Zool 17:435-504

US Fish and Wildlife Service (1991) Endangered and threatened wildlife and plants; Point Arena mountain beaver (Aplodontia rufa nigra) determined to be endangered. Fed Regist 56:64716-64723

US Fish and Wildlife Service (1998) Point Arena mountain beaver (Aplodontia rufa nigra (Rafinesque)) recovery plan. Region 1, Portland

US Fish and Wildlife Service (2009) Point Arena mountain beaver (Aplodontia rufa nigra) 5-year review: summary and evaluation. Unpublished report on file at US Fish and Wildlife Service, Arcata Fish and Wildlife Office, Arcata

Walker R, Craighead L (1997) Analyzing wildlife movement corridors in Montana using GIS. In: Proceedings of the ESRI European User conference, Copenhagen, pp 1-18

Wang IJ, Savage WK, Shaffer HB (2009) Landscape genetics and least-cost path analysis reveal unexpected dispersal routes in the California tiger salamander (Ambystoma californiense). Mol Ecol 18:1365-1374

Waples RS, Do C (2008) LDNE: a program for estimating effective population size from data on linkage disequilibrium. Mol Ecol Resour 8:753-756

Waples RS, Do C (2010) Linkage disequilibrium estimates of contemporary $\mathrm{Ne}$ using highly variable genetic markers: a largely untapped resource for applied conservation and evolution. Evol Appl 3:244-262

Weir BS, Cockerham CC (1984) Estimating F-statistics for the analysis of population structure. Evolution 38:1358-1370

Zielinski WJ, Schlexer FV, George TL, Pilgrim KL, Schwartz MK (in review) Estimating population size and survival in the endangered Point Arena mountain beaver (Aplodontia rufa nigra) using noninvasive genetic methods. J Fish Wildl Manag 
Table S1. Results of matrix regression in explaining genetic distance for Point Arena mountain beaver sites with 3 or more individuals $(n=9)$. Values are partial Mantel $r$ values ( $P$ value); ns indicates a $P$ value $>0.05$.

\begin{tabular}{|c|c|c|c|c|}
\hline Scenario & $\begin{array}{c}\text { Geographic } \\
\text { distance }\end{array}$ & $\begin{array}{c}\text { LCP } \\
\text { distance }\end{array}$ & $\begin{array}{c}\text { LCP distance } \\
\text { (partial Mantel r) }\end{array}$ & $\begin{array}{c}\text { Geographic distance } \\
\text { (partial Mantel r) }\end{array}$ \\
\hline Cost 1 & $0.11(0.07)$ & $0.21(0.006)$ & $0.56(0.005)$ & ns \\
\hline Cost 2 & $0.11(0.07)$ & $\mathrm{ns}$ & ns & ns \\
\hline Cost 3 & $0.11(0.07)$ & $0.15(0.014)$ & ns & ns \\
\hline Cost 4 & $0.11(0.07)$ & $0.10(0.08)$ & ns & ns \\
\hline Cost 5 & $0.11(0.07)$ & $0.28(0.001)$ & $0.51(0.01)$ & $\mathrm{ns}$ \\
\hline Cost 6 & $0.11(0.07)$ & $0.29(0.004)$ & $0.54(0.01)$ & ns \\
\hline Cost 7 & $0.11(0.07)$ & $0.40(0.003)$ & $0.57(0.007)$ & $\mathrm{ns}$ \\
\hline Cost 8 & $0.11(0.07)$ & $0.37(0.003)$ & $0.54(0.011)$ & $\mathrm{ns}$ \\
\hline Cost 9 & $0.11(0.07)$ & $0.36(0.004)$ & $0.53(0.015)$ & ns \\
\hline Cost 10 & $0.11(0.07)$ & $0.40(0.002)$ & $0.57(0.003)$ & ns \\
\hline Cost 11 & $0.11(0.07)$ & $0.40(0.002)$ & $0.57(0.005)$ & ns \\
\hline Cost 12 & $0.11(0.07)$ & $0.40(0.001)$ & $0.57(0.011)$ & $\mathrm{ns}$ \\
\hline Cost 13 & $0.11(0.07)$ & $0.31(0.005)$ & $0.47(0.03)$ & $\mathrm{ns}$ \\
\hline Cost 14 & $0.11(0.07)$ & $0.41(0.002)$ & $0.58(0.007)$ & ns \\
\hline Cost 15 & $0.11(0.07)$ & $0.23(0.006)$ & $0.44(0.04)$ & $\mathrm{ns}$ \\
\hline Cost 16 & $0.11(0.07)$ & $0.12(0.06)$ & ns & ns \\
\hline
\end{tabular}


Table S2. Results of matrix regression in explaining genetic distance for Point Arena mountain beaver sites with nine or more individuals $(n=6)$. Values are partial Mantel $r$ values $(P$ value $) ;$ ns indicates a $P$ value $>0.05$

\begin{tabular}{|c|c|c|c|c|}
\hline Scenario & $\begin{array}{c}\text { Geographic } \\
\text { distance }\end{array}$ & $\begin{array}{c}\text { LCP } \\
\text { distance }\end{array}$ & $\begin{array}{c}\text { LCP distance } \\
\text { (partial Mantel r) }\end{array}$ & $\begin{array}{l}\text { Geographic distance } \\
\text { (partial Mantel r) }\end{array}$ \\
\hline Cost 1 & $0.11(0.10)$ & $0.27(0.02)$ & $0.58(0.02)$ & ns \\
\hline Cost 2 & $0.11(0.10)$ & $0.14(0.07)$ & ns & ns \\
\hline Cost 3 & $0.11(0.10)$ & $0.14(0.05)$ & $\mathrm{ns}$ & $\mathrm{ns}$ \\
\hline Cost 4 & $0.11(0.10)$ & $0.11(0.09)$ & $\mathrm{ns}$ & ns \\
\hline Cost 5 & $0.11(0.10)$ & $0.28(0.01)$ & $\mathrm{ns}$ & ns \\
\hline Cost 6 & $0.11(0.10)$ & $0.30(0.01)$ & $0.50(0.09)$ & ns \\
\hline Cost 7 & $0.11(0.10)$ & $0.41(0.017)$ & $0.58(0.08)$ & ns \\
\hline Cost 8 & $0.11(0.10)$ & $0.35(0.025)$ & $0.52(0.09)$ & ns \\
\hline Cost 9 & $0.11(0.10)$ & $0.30(0.03)$ & ns & ns \\
\hline Cost 10 & $0.11(0.10)$ & $0.41(0.007)$ & $0.58(0.07)$ & ns \\
\hline Cost 11 & $0.11(0.10)$ & $0.41(0.018)$ & $0.58(0.08)$ & ns \\
\hline Cost 12 & $0.11(0.10)$ & $0.41(0.014)$ & $0.58(0.09)$ & $\mathrm{ns}$ \\
\hline Cost 13 & $0.11(0.10)$ & $0.24(0.03)$ & $\mathrm{ns}$ & ns \\
\hline Cost 14 & $0.11(0.10)$ & $0.44(0.03)$ & $0.62(0.07)$ & ns \\
\hline Cost 15 & $0.11(0.10)$ & $0.34(0.01)$ & $0.64(0.01)$ & ns \\
\hline Cost 16 & $0.11(0.10)$ & $0.11(0.09)$ & ns & ns \\
\hline
\end{tabular}



Figure S1. Relationship of variance in group membership to number of groups $(k)$, from $1-$ 10, as estimated by program STRUCTURE. Note inflection point at approximately $k=3$.

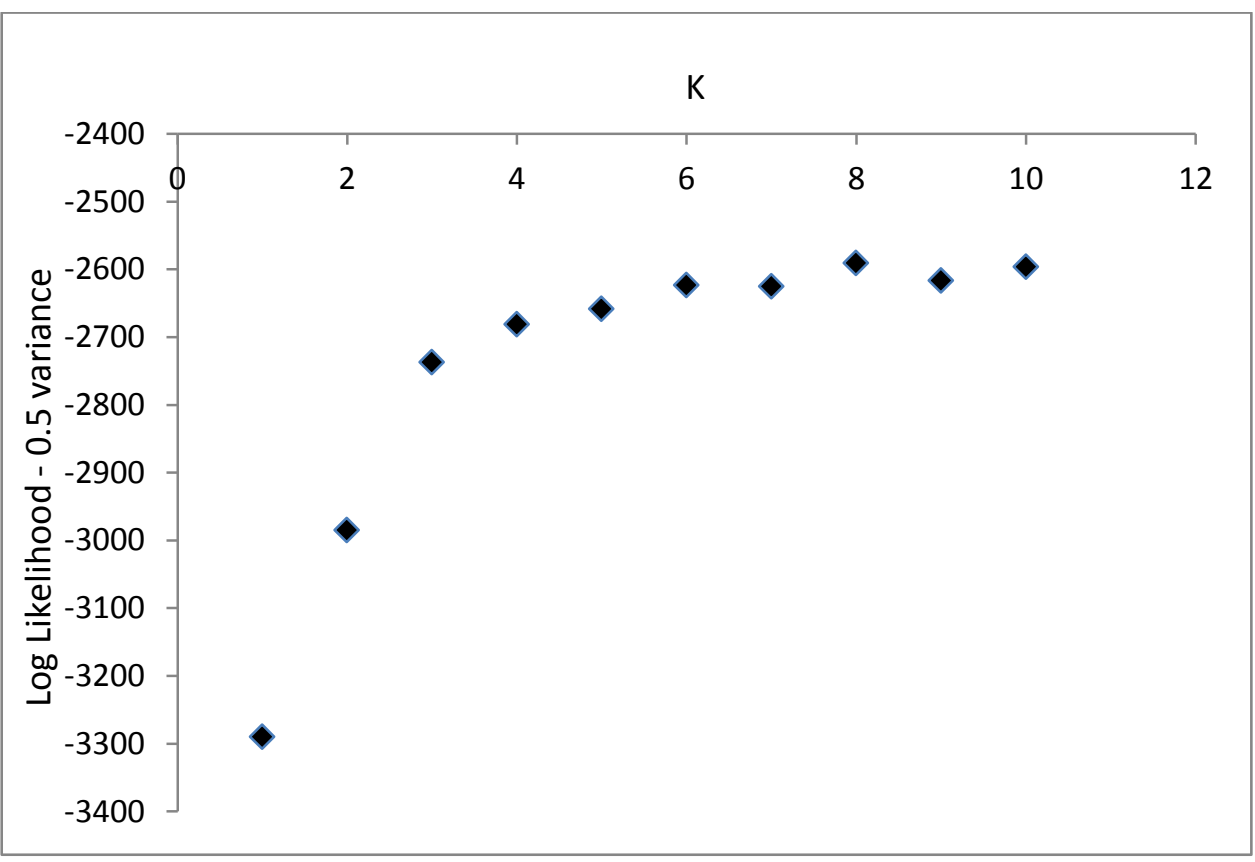


Figure S2. Graphical representation of structure analysis for the Point Arena mountain beaver when considering $k=3$ groups. Each vertical line represents an individual. Individuals are ordered from north to south and thin horizontal lines divide the samples into the 17 sites described in Table 1B. The 3 shades of gray represent the inferred ancestry (or proportion of each individual from the 3 groups).
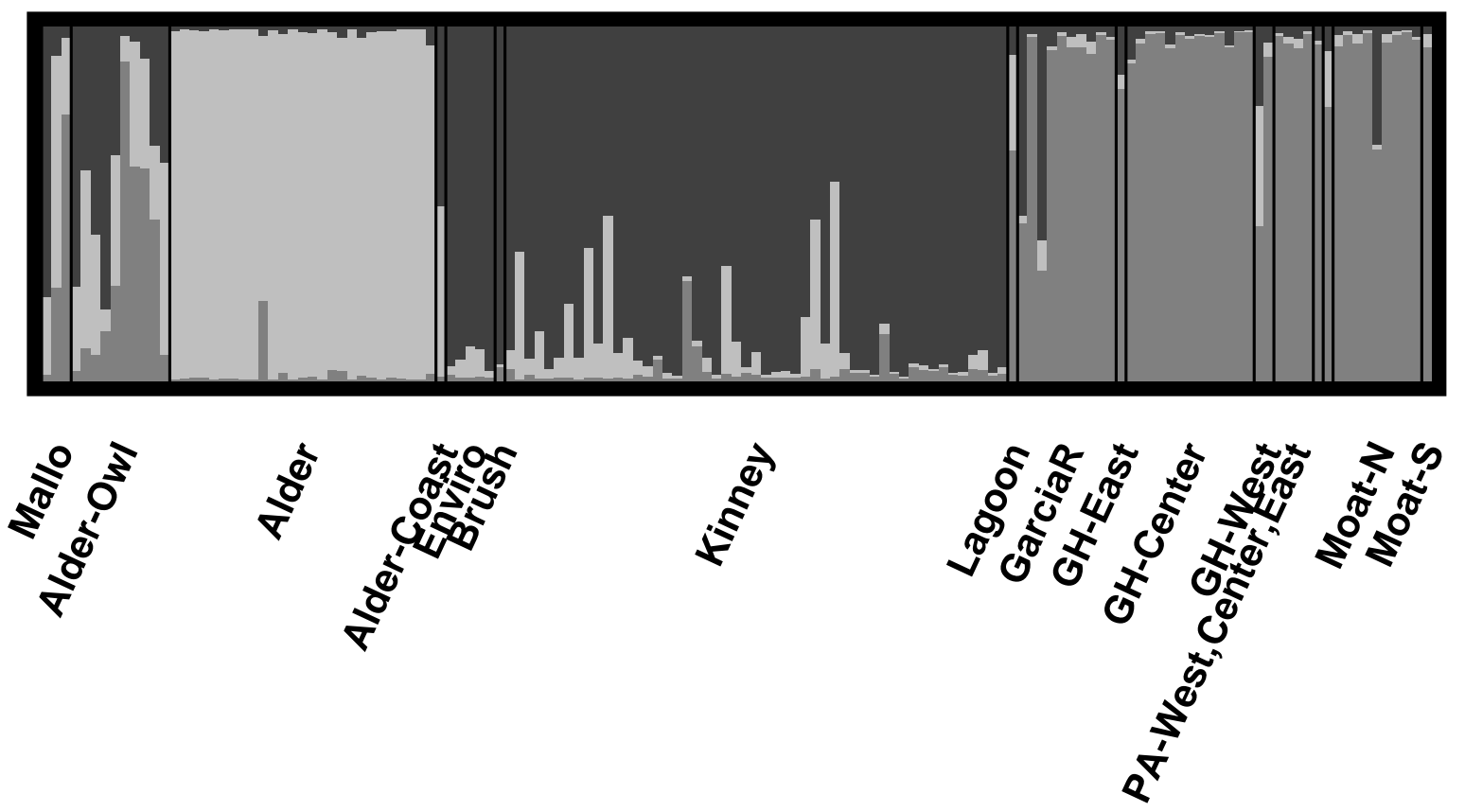